\title{
Study on Coordinated Development of New Urbanization and New Rural Construction
}

\author{
Hongwei Cui \\ Jilin Business and Technology College \\ Changchun, China 130507
}

\begin{abstract}
Coordinated development of new urbanization and new rural construction is a complicated systematic project, it is a new development strategy with distinct characteristics. This paper will analyze the connotation of coordinated development between new urbanization and new rural construction, then discuses the interaction between them.
\end{abstract}

Keywords-new urbanization; new rural construction; interaction; coordinated development

\section{INTRODUCTION}

The new rural construction and urbanization are two important aspects of the drive of modernization. They promote each other and complement each other. The new pattern of urbanization development calls for the construction of new countryside, and also it is an important way to promote the construction of new rural areas. Socialist new rural construction is conducive to the realization of rural urbanization, transfer rural surplus labor, and promote the increase of farmers; at the same time socialist new rural construction can improve the rural infrastructure, and realize urbanization better. So they should be combined to achieve a positive interaction, which is a major role in promoting the development of rural economy in china.

The practice proved that the degree of urbanization and new rural construction speed is proportional to be better, degree of urban and rural economic and social development can be better. Only the new rural construction and urbanization more closely integrated, to the greatest extent of urbanization in the new rural areas of blessing shot, aggregation and even leading role, it can be more smoothly to speed up the development of urban and rural coordination, and achieve complementary, complement each other.

\section{CONNOTATION OF COORDINATED DEVELOPMENT BETWEEN NEW URBANIZATION AND NEW RURAL CONSTRUCTION}

Urbanization is an important measure of a country's social progress and rural modernization. Accelerate the development of urbanization which can help to promote the upgrading of economic structure and optimize, accumulation of the development of rural industry, but also conducive to build a new socialist countryside. Connotation of urbanization is improving and rich with economic development and social progress, which is a complex process of change involving economic, social and cultural, and many other factors. For now, our country's urbanization is the process in rural areas into urban or rural to urban mobility, causing changes in the dynamic process of many aspects of social behavior and economic activity. New urbanization with Chinese characteristics is to build a harmonious society and intensive economic development as the goal, through interaction with the new industrialization, agricultural modernization and information, with integration of urban and rural integration, strong industry, beautiful ecological environment, full employment opportunities for urbanization. [1]

Building a new socialist countryside is relative to the original terms of urban and rural development, it is a major development strategy that the CPC Central Committee put forward in the new era, and it is the choice of our current economic and social development which is realistic, rational, and inevitable. Party Plenum proposed, according to the requirements of the "production development, affluent life, rural civilization, clean and tidy village, democratic management", and comprehensively promotes the new situation for economic, political, cultural, social and Party construction of rural. This is the current connotation manifestation of socialist new countryside. [2]

Although there are differences in foothold of new urbanization and new rural construction, but there are inherent association between them, so they can achieve coordinated development. The new coordinated development of urbanization and new rural construction refers to the government in order to solve the rural and urban development process of mutual economic, social and cultural issues, use the economic, legal and administrative measures, balance the relationship between internal factors system, so that new urbanization and new rural construction forming benign interaction mechanism as a unified system, achieve urban-rural dual structure to a unitary structure.

In summary we can see that new urbanization and new rural construction are the two carriers to achieve socialist modernization, they are complementary, indivisible and mutually reinforcing. In essence, the new urbanization is the driving force and purpose to build a new socialist countryside and it is the bridge and intermediaries to achieve rural development to urban construction which is an objective law of rural development and the inevitable trend. Building a new socialist countryside can provide a new 
impetus and new opportunities for urbanization, is the only way to promote the development of urbanization. In short, there are differences between them; there are some contradictions in the policy background, element configuration, etc. But the new urbanization and new rural construction is uniform in nature, belong to a problem in two ways. We have to find ways to improve both so that they can be benign interaction, enhance the degree of integration of urban and rural areas.

\section{THE NEW RURAL CONSTRUCTION IS COMPLEMENTARY TO NATIONAL NEW URBANIZATION STRATEGY}

New urbanization and new rural construction are complementary; in essence, the new rural construction is complementary to national urbanization strategy. In the process of urbanization, if ignore an important role in economic development in rural areas, then urbanization will be bound by lack of resource supply.

First, "production development" in new rural construction provides the foundation for the economic development of urbanization. "Production development" is the primary development goal of new rural construction, it can provide a lot of agricultural surplus for new urbanization, create material basis for promoting its development. Rural "production development" means to speed up the transformation of traditional rural, constantly adjusting the industrial structure, change production methods, increase resources, supply factors, driven by industrialization of rural industrialization, and then driven by industrialization and urbanization, thus speeding up the process of urbanization in rural areas.

Second, "affluent life "in the new rural construction provides market foundation for the development of urbanization. In the process of building new socialist countryside, with the deepening of the reforms, farmers' per capita income levels will gradually increase, consumption will continue to increase; the market can lay the foundation for the new urbanization. Meanwhile, if farmers have affluent lives, they will be more longing the lifestyle of relatively civilized urbanization; it will generate a lot of rural surplus labors. Those can provide a solid market foundation.

Third, "rural civilization" in the new rural construction provides social foundation for the development of urbanization. The process of "rural civilization" is continuously to improve the quality of farmers. New socialist countryside construction, efforts to cultivate new farmers, high-quality rural labors flow into the city and township enterprises, will best meet the needs of high-quality migrant workers, and thus ease the process of urbanization due to the influx of low quality labor, and violent crime to the city caused by unemployment and other social pressures. In short, the new rural construction to prepare for urbanization on the quality of the population provides the necessary intelligence and personnel support for the new urbanization, thereby reducing the social costs of urbanization.
Fourth, "clean village" in the new rural construction provides the foundation for the development of urbanization environment."Clean village" is an effective vehicle and explicit state for new socialist countryside. Village is clean that requirements village layout should be reasonable, ecological environment is good, infrastructure is perfect, those will make the town take more attention to ecological environment, industrial layout and infrastructure planning in the process of new urbanization. "Clean village" in new rural construction laid the foundation for the new environment and spatial development of urbanization.

Fifth, "democratic management" in the new rural construction provides political basis for the development of urbanization. Democratic management is to enhance farmers' right in the rural economic and social development. The main building of new socialist countryside, including not only the farmers in rural areas, but also including the city's farmers who already are in or in the future will be in, therefore, the rural affairs management model of democracy can resolve all kinds of obstacles and risks, and lay a solid mass political base for development for new urbanization.

\section{NEW Urbanization IS A BoOster of NEW RURAL CONSTRUCTION}

New urbanization can achieve strategic mission of socialist countryside and provide the most important way for it.

First, the health of rural urbanization is in favor of a new realization of "production development". Development of rural, industrialization is the pillar and inevitable way. If there is no development of industrial, it is unable to build a new socialist countryside. Therefore, the new rural construction must focus on industrialization, and then urbanization can become inevitable. Urbanization can attract all kinds of rural township enterprises together to overall arrangement of resources and improve economic efficiency, thus promoting the healthy development of township enterprises in rural areas. Meanwhile, improvement in the level of urbanization can accelerate the agricultural industry structure and adjustment of economic structure, thus improving the efficiency of agricultural production and agricultural production capacity. With the continuous development of urbanization, industrial development of the city will expand elements of the demand for rural areas, while upgrading of urban industrial structure can radiation surrounding rural areas, urban and rural areas can gradually be assimilation.

Second, the health of rural urbanization is in favor of new realization of "affluent life". Urbanization development can enhance farmers' income space, conducive to stimulate domestic demand, and provide power to support new rural construction. On the one hand, urbanization is an important channel for the transfer of rural surplus labor that can provide employment opportunities for the rural surplus labors, to increase the income of farmers. On the other hand, farmers come into the cities and towns and become consumers of agricultural products, can expand the demand for agricultural products, so the total consumption needs of 
the community will increase, thereby increasing of demand for the production of further stimulating rural development. Increasing in demand can further boost the development of rural production that can achieve "affluent life" in new countryside.

Third, the health of rural urbanization is in favor of a new realization of "rural civilization". Urbanization can inherit and carry forward the fine traditional culture on the basis of the countryside, through the dissemination of extension staff mobility and spatial information, with urban civilization affecting rural civilization. Town gathered advanced elements of life and management elements, that can spread the advanced ideas and culture of city to the countryside, and get rid of bad habits in rural areas, promote civilization of rural and urban, and continuously improve the quality of farmers and promote rural social progress, and form healthy social habits and lifestyle, and achieve "rural civilization" in new countryside.

Fourth, healthy urbanization in favor of achieving "clean and tidy village" on the one hand, healthy urbanization regulate the use of land resources in rural areas through scientific planning, to avoid extensive development, deforestation, reducing emissions, waste water, solid waste material emissions, thus maintaining the ecological balance. On the other hand, urbanization expropriation land through the planning, and implementation of environmental engineering, can improve the rural landscape to achieve "clean and tidy village" in new countryside.

Fifth, healthy urbanization is in favor of the new rural to achieve "democratic management". Urbanization accelerated the democratic process in rural areas. Urbanization is the process of spreading urban civilization and political ideas to the vast rural areas, but also increasingly narrowing the gap between the process of allocation of public goods and medical, health, education and other urban and rural areas, which create a spiritual and material conditions to achieve "managed democracy" in rural areas. At the same time, urbanization through demonstration model of democracy will incorporate democratic political life of farmers into the advanced orbit, so that the majority of farmers can share the fruits of socialist construction, thus achieving "democratic management" in new countryside.

\section{REFERENCES}

[1] Jiangjing.Study on Utilization of Land under the New Urbanization Background. Entrepreneurs World, 2010 (12) :26.

[2] Liuwenjian. Urbanization and Building a New Socialist Countryside. Journal of Economic Management Personnel Institute in Shandong Province, 2006 (2):32.

[3] Wuxiongzhou. Study on Coordinated Development of New Rural Construction and Urbanization in Hunan Province. Agricultural University Doctoral Dissertation in Hunan Province, 2010:23. 